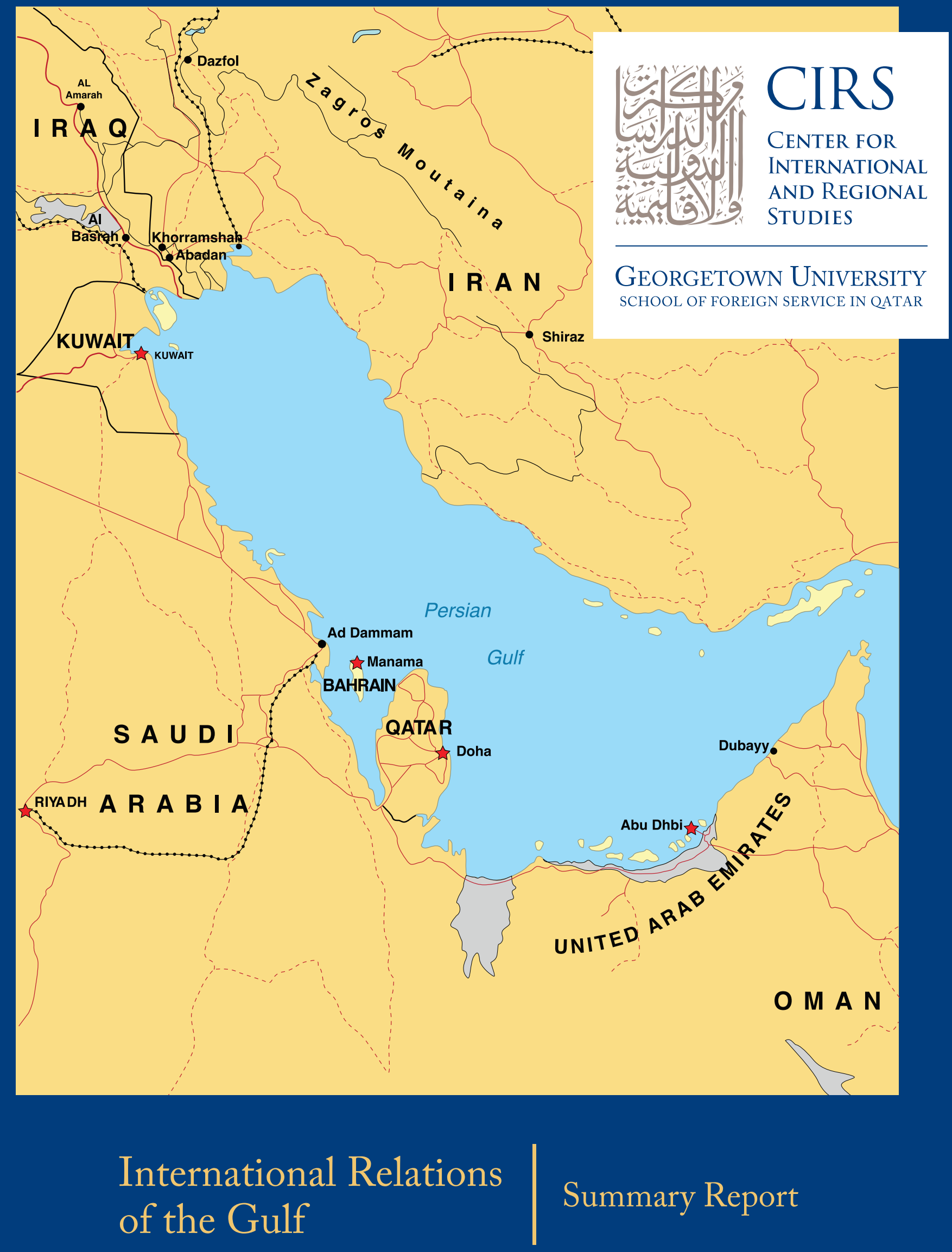




\section{About the Georgetown University School of Foreign Service in Qatar}

The Georgetown University School of Foreign Service in Qatar, opened in August 2005, is a branch campus of Georgetown University, the oldest Catholic and Jesuit university in America, founded in 1789. The program builds on Georgetown University's long tradition of educating future leaders for careers in the international arena through a liberal arts undergraduate program focused on international affairs. For more information about the School of Foreign Service in Qatar, please visit http://qatar.sfs.georgetown.edu.

\section{About the Center for International and Regional Studies}

Established in 2005, the Center for International and Regional Studies at the Georgetown University School of Foreign Service in Qatar is a premier research institute devoted to the academic study of regional and international issues through dialogue and exchange of ideas, research and scholarship, and engagement with national and international scholars, opinion makers, practitioners, and activists.

Guided by the principles of academic excellence, forward vision, and community engagement, the Center's mission revolves around five principal goals:

- To provide a forum for scholarship and research on international and regional affairs

- To encourage in-depth examination and exchange of ideas

- To foster thoughtful dialogue among students, scholars and practitioners of international affairs

- To facilitate the free flow of ideas and knowledge through publishing the products

of its research, sponsoring conferences and seminars, and holding workshops

designed to explore the complexities of the twenty-first century

- To engage in outreach activities with a wide range of local, regional and international partners

\section{About the Qatar Foundation for Education, Science and Community Development}

Founded in 1995 by decree of His Highness Sheikh Hamad Bin Khalifa A1 Thani, Emir of Qatar, Qatar Foundation is a non-profit organization focusing on education, scientific research and community development. Under Qatar Foundation's umbrella are Education City which comprises elite universities, several academic and training programmes and Qatar Science and Technology Park which boasts more than 21 world class companies involved in scientific research and development.

Chaired by Her Highness Sheikha Mozah bint Nasser Al Missned, Qatar Foundation also aims to enhance lives through community development initiatives including Doha Debates, Reach out To Asia and Al Jazeera Childrens Channel.

Joint venture partnerships in the areas of design, ICT, telecommunications, policy studies and event management contribute to fulfilling the objectives of Qatar Foundation.

This publication is made possible by the generous support of Qatar Foundation for Education, Science and Community Development.

Cover Design by Assma Al-Adawi 


\section{The International Relations of the Gulf Working Group Summary Report}

(C) 2009 Center for International and Regional Studies Georgetown University School of Foreign Service in Qatar 



\title{
The International Relations of the Gulf
}

\author{
Working Group Summary Report
}

This Summary Report details the research findings that were presented by the International Relations of the Gulf working group participants during their meetings in Doha, Qatar, hosted by the Center for International and Regional Studies (CIRS) at the Georgetown University School of Foreign Service in Qatar. The International Relations of the Gulf research initiative is a two-part scholarly project dealing with in-depth academic and policy analysis of the Gulf's strategic position in world politics. The first phase of the initiative began in June 2008 and focused on outlining the study of several key aspects of the international relations of the Gulf from different theoretical angles. CIRS invited a core group of Gulf studies scholars to Doha to attend the International Relations of the Gulf working group meetings and to contribute individual chapters on an area of their expertise towards a book of the same name. This initial round of talks consisted of preliminary thoughts on chosen topics and brainstorming sessions to critically assess the project's focus, parameters of analysis, and main thesis. The working group was invited back to Doha in January 2009 to complete the second phase of the project and submit their individual papers for peer review. Concomitantly, CIRS invited several other experts in the field to act as discussants and to give critical consultation to the project and enrich the topics under examination.

The book will be the first of its kind to be published by an educational institution based in Qatar, and breaks new ground in the literature on the international relations of the Middle East in general and the Gulf in particular. This research situates the Gulf within a complex web of interconnected political and economic structures. One cannot discuss the Gulf as though it were an autonomous region. This research emphasizes the complex international relations of the Gulf by arguing that Asian countries such as Pakistan and India are as influential in Gulf politics as other countries in the Middle East. The entire region is a security and energy complex impacted by a variety of internal and external actors.

This research initiative will explore critical issues such as security strategies and foreign policy implications of political reforms in the Gulf region, questions of sovereignty and borders, American policy, and the foreign and security policies of Iran, Iraq, Saudi Arabia, Qatar, and other regional actors. 
International Relations of the Gulf

Working Group Participants and Contributors

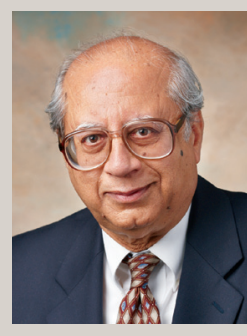

Mohammed Ayoob

Michigan State University

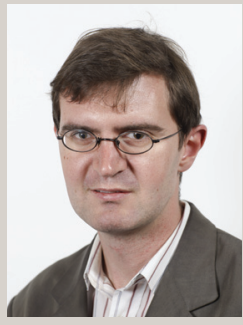

Kristian Coates Ulrichsen

London School of Economics and Political Science

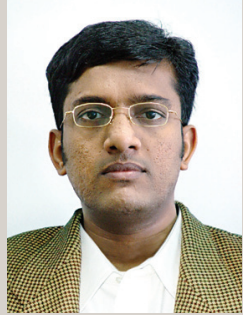

N. Janardhan

Gulf-Asia Affairs, UAE

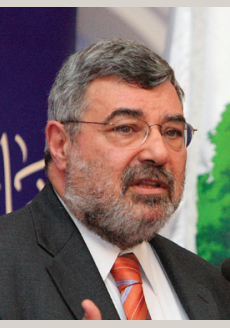

Rami Khouri

American University of Beirut

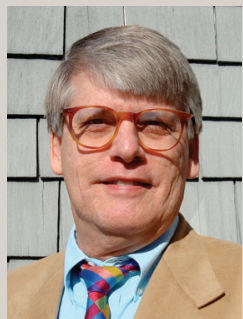

Fred Lawson

Mills College

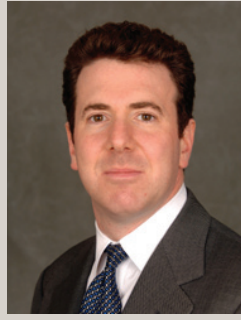

Daniel Byman

Georgetown University

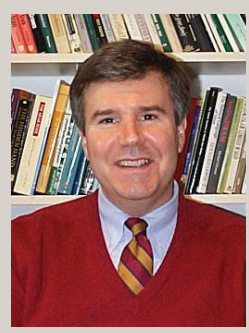

Gregory Gause

University of Vermont

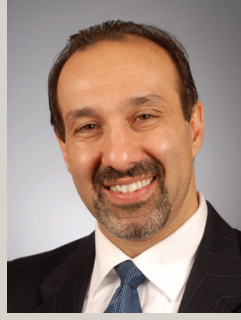

Mehran Kamrava

Georgetown University

School of Foreign Service in Qatar

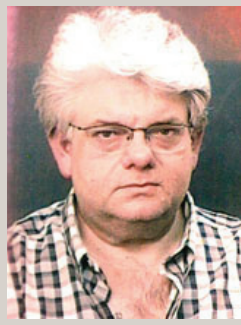

Joseph Kostiner

Tel Aviv University

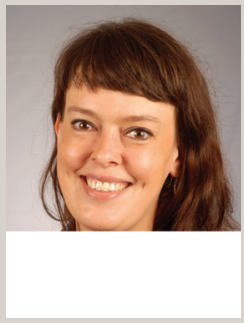

Katja Niethammer

Hamburg University 

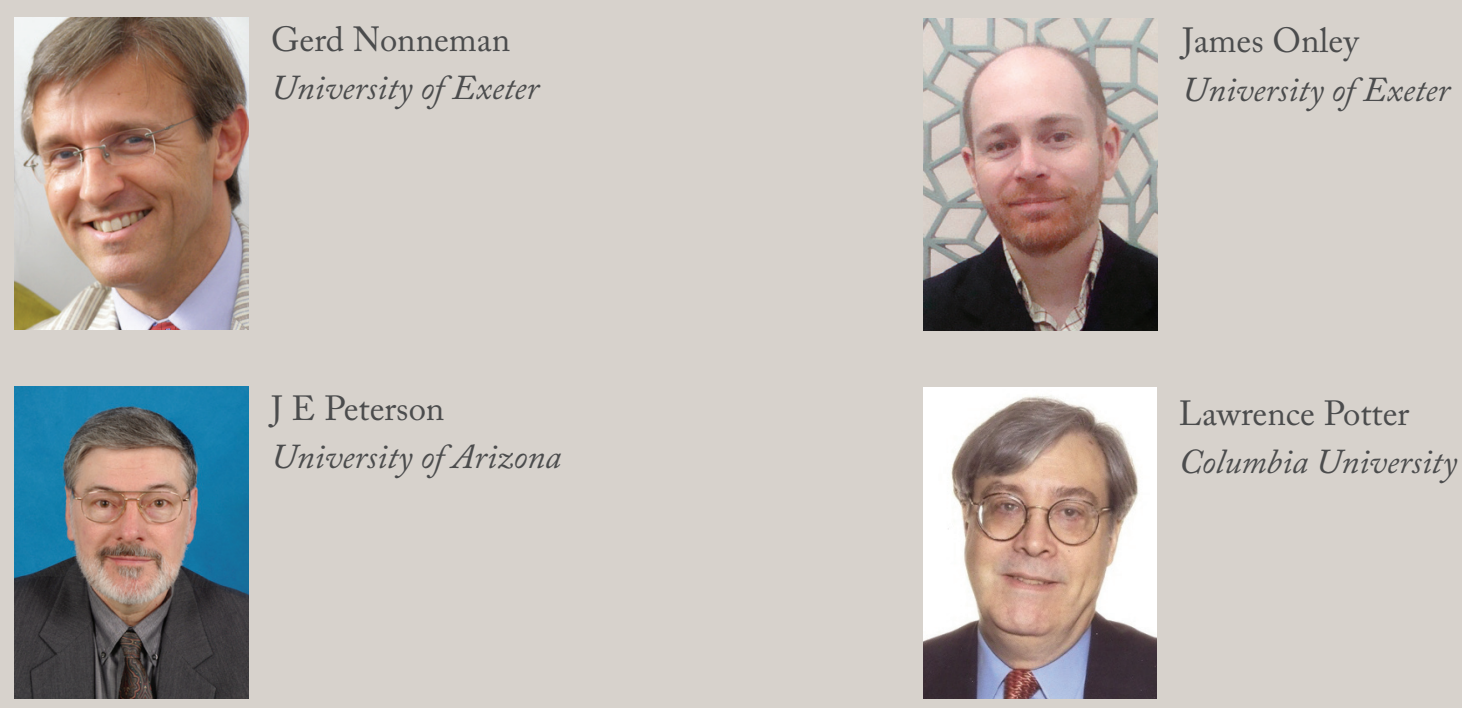

J E Peterson

University of Arizona

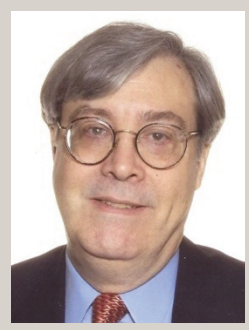

Lawrence Potter

Columbia University

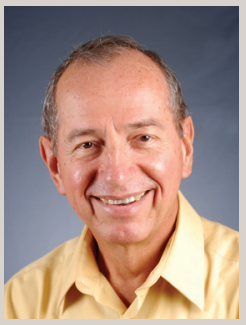

Robert Wirsing

Georgetown University

School of Foreign Service in Qatar

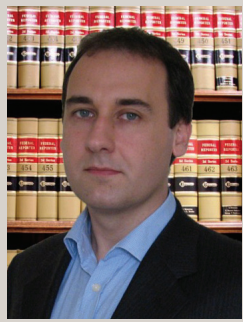

Steven Wright

Qatar University 



\title{
Table of Contents
}

\author{
Paper Synopses
}

1. Introduction

Mehran Kamrava, Georgetown University School of Foreign Service in Qatar

2. Britain and the Gulf Shaikhdoms, 1820-1971: The Politics of Protection

James Onley, University of Exeter

3. Sovereignty and Boundaries in the Gulf States: Settling the Peripheries

J.E. Peterson, University of Arizona

4. Security Dilemmas in the Contemporary Persian Gulf

Fred H. Lawson, Mills College

5. The GCC States' Perceptions of Collective Security in the Early 21st Century

Joseph Kostiner, Tel Aviv University

6. American Policy toward the Persian Gulf: Strategies, Effectiveness, and Consequences

Mohammed Ayoob, Michigan State University

7. The Iraq Factor: Regional Consequences of Internal Turmoil

Daniel Byman, Georgetown University

8. Saudi Arabia's Regional Security Strategy

F. Gregory Gause, III, University of Vermont

9. Iran's Regional and Foreign Security Policies in the Persian Gulf

Mehran Kamrava, Georgetown University School of Foreign Service in Qatar

10. Qatar's Foreign Policy: Autonomy and Security

Steven Wright, Qatar University

11. China, India, and the Gulf: Converging Interests?

N. Janardhan, Gulf-Asia Affairs, UAE

12. Political Reform and Foreign Policy in the Gulf Monarchies

Katja Niethammer, Hamburg University

13. Conceptualizing EU-GCC Relations

Gerd Nonneman, University of Exeter 



\section{Introduction: The Changing International Relations of the Persian Gulf}

Mehran Kamrava

Observers of the Persian Gulf agree that the strategically critical region is undergoing profound changes. These changes affecting the region run the gamut from rapid economic and infrastructural development to profound social and cultural changes resulting from diffusion, globalization, and the widespread introduction of American-style education. This research initiative concentrates on a series of changes underway in the Persian Gulf that have heretofore been understudied, namely in the region's international relations. Far from eroding the region's strategic significance, these changes have only accentuated regional rivalries and tensions, thrown into confusion previously somewhat predictable patterns of foreign policy behavior, and have brought to fore new challenges to regional security and stability. This initiative examines some of the most salient underlying causes for changes in the region's international relations and the consequences that each of these changes has entailed both in the specific areas they concern and in the broader context of international relations in the Persian Gulf, in the larger Middle East, and beyond.

Perhaps one of the most striking features of the international relations of the Persian Gulf is its securitization. For a variety of reasons, ranging from the nature of political rule within each of the countries of the region to the ways in which their international interactions have evolved historically, much of the international politics of the Persian Gulf has focused on security issues of one form or another. The region has faced, and continues to face, multiple security challenges, and there have been a number of attempts, thus far not all that successful, to forge collective security arrangements. Not surprisingly, much of the efforts and involvements of actors in the Persian Gulf, whether from within or outside of the region (the US and the European Union), has occurred either directly because of or at least with an eye toward security issues. Threats, or at least perceptions of threats, have lurked in the shallow waters and the sandy beaches of the Persian Gulf as far back as the early days of the British Empire, and those engaged in the region's international politics have been unable to escape the multiple concerns to which they have given rise. This is not to imply, of course, that all of the Persian Gulf's international politics can be reduced to issues of security, but rather to argue that security issues have never been far from consideration insofar as regional politics are concerned.

My goals in this introductory synopsis are two-fold: to outline some of the broader themes that have been consequential in the international relations of the Persian Gulf, and to also highlight some of the changes that have occurred to the emerging security system of the region over the last three decades or so. These have resulted in a number of challenges with which both regional actors and those from the outside have had to contend. I will begin by briefly outlining the main reasons for the continuing strategic significance of the Persian Gulf, not only because of its vast oil and gas deposits but also because of its emergence as a global hub of commerce and finance, the growing postures of Dubai and Doha as major entrepôts for the rest of the region and beyond, the apparent rise in Iranian influence in Iraq and Afghanistan, and continuing tensions between Iran on the one side and the US and Israel on the other. Concurrently, there have been major, tectonic changes in the Persian Gulf's prevailing security system, with imperial hegemonic tendencies-Britain before 1971 and the US from 2001 to 2008-competing with or giving way to balance-of-power politics, containment, and anarchy and confusion. Today, the Persian Gulf security system stands at the precipice of change, the ultimate shape of which will not be determined for a good few years. All of this, of course, entails challenges, some endogenous to the region and others exogenous. This research initiative highlights 
some of the more pressing security challenges the region faces, calling attention also to the very unpredictability of their intensity, direction, and ultimate fate. The more specific discussions and conclusions of the synopses that follow bring to light some of the broader trends and dynamics I have outlined here.

Mehran Kamrava is Interim Dean of the Georgetown University School of Foreign Service in Qatar and Director of the Center for International and Regional Studies. In addition to a number of journal articles, he is the author of Revolution in Iran: The Roots of Turmoil (1990), The Political History of Modern Iran: From Tribalism to Theocracy (1992), Revolutionary Politics (1992), Understanding Comparative Politics: A Framework for Analysis, 2nd ed. (2008), Democracy in the Balance: Culture and Society in the Middle East (1998), Cultural Politics in the Third World (1999), Politics and Society in the Developing World, 2nd ed. (2000), The Modern Middle East: A Political History since the First World War (2005), and Iran's Intellectual Revolution (2008). He has also edited The New Voices of Islam: Rethinking Politics and Modernity (2006) and is the co-editor of the two-volume work Iran Today: Life in the Islamic Republic (2008). 


\section{Britain and the Gulf Shaikhdoms, 1820-1971: The Politics of Protection}

James Onley

British interests in Eastern Arabia originally grew out of a need to protect British India's ships and subjects in Arabian waters. British hegemony in the region dates from 1820, when the British Indian Government sent a devastating naval expedition against Sharjah and Ras al-Khaimah, whose population it held responsible for increasingly frequent maritime raids on British Indian shipping in and around the Persian Gulf. After the expedition, the British imposed an anti-piracy treaty - known as the General Treaty of 1820 - on all the rulers and governors of what is now the United Arab Emirates. The Ruler of Bahrain was admitted to the General Treaty at his request to protect Bahraini ships from maritime raiding.

After the imposition of the General Treaty of 1820 , the rulers of the Gulf shaikhdoms consented to other treaties over the course of the century. The most important of these were the Maritime Truces, which established the Pax Britannica in the Persian Gulf. The first Maritime Truce - proposed by the Ruler of the Qasimi empire (Sharjah, Ras al-Khaimah and their dependencies) and signed in 1835 by the rulers of Abu Dhabi, Dubai, Ajman and the Qasimi empire - was an experimental ban on maritime warfare during the pearling season. The Truce was a great success and was renewed again and again until a permanent truce was signed in 1853. In recognition of the shaikhdoms' membership in the Maritime Truce, the British referred to them as the "Trucial States" and to the Coast of Oman as the "Trucial Coast." The British eventually invited the rulers of Bahrain and Qatar to join the Truce in 1861 and 1916 respectively. Under the terms of the Truce, the Gulf rulers gave up their right to wage war by sea in return for British protection against maritime aggression. This arrangement, known as the "Trucial system," cast Britain in the roles of protector, mediator, arbiter, and guarantor of settlements. Later on, the rulers also signed Exclusive Agreements with Bahrain in 1880 and 1892, the Trucial States in 1888 and 1892, Kuwait in 1899, Najd and Hasa in 1915 (annulled in 1927), and Qatar in 1916, binding them into exclusive treaty relations with, and ceding control of their external affairs to, the British Government of India.

To manage British India's relations with these rulers, supervise the enforcement of the treaties, and protect British India's ships and subjects in Arabian waters, the British created the post of Political Resident in the Persian Gulf, headquartered at Bushire in southwest Iran until 1947, when he moved to Bahrain. The Resident visited the Gulf shaikhdoms only once a year in the nineteenth century and twice a year in the twentieth. To conduct Britain's diplomatic relations with the rulers of the Gulf shaikhdoms on a daily basis, he maintained subordinate political agents at Muscat (c.1758-1971), Manamah (c.1816-1971), Sharjah (1823-1953), Dohah (1949-71), Dubai (1953-71), and Abu Dhabi (1957-71), as well as the Omani enclave of Gwadar in what is now Pakistan (1863-1958).

The international legal status of the Gulf shaikhdoms was that of British-protected states: although their rulers remained as heads of state, their status vis-à-vis the British Government of India and (after 1947) the British Government in London placed them informally within the British Empire. Between the 1880s and 1947, the shaikhdoms formed a cordon sanitaire protecting the western approaches to British India. Britain's exclusion of foreign involvement in the Gulf was intended in part to prevent Britain's rivals from establishing a naval base in the Gulf, for such a base would pose a serious maritime threat to India. After the discovery of oil in the region, Britain became dependent on Gulf oil. This dependence contributed to Britain's decision to stay on in the Gulf after its withdrawal from India in 1947.

The British saw several advantages in recognizing only the most powerful coastal rulers in the Persian Gulf. Britain's Gulf Resident found it easier to deal with a few key rulers than with all the rulers and tribal shaikhs in the region. 
Likewise, it was easier and preferable for the rulers themselves to enforce the various Anglo-Arab treaties (such as the anti-piracy and anti-slave-trade agreements), and for the Resident to hold the rulers accountable for their subjects' transgressions, than for the Resident to enforce the treaties directly and punish the transgressors himself.

The basis of British power in the Persian Gulf was its navy. The Persian Gulf Squadron patrolled the waters of the Gulf to enforce the General Treaty, the Maritime Truce, and the various treaties banning the shipment of slaves and arms - an activity known as "watch and cruise."

For the Gulf rulers there were numerous advantages and disadvantages to British protection. First, the rulers reinforced their positions within their shaikhdoms and enhanced the political status of their shaikhdoms within the regional political system. The British also provided important external recognition of the most powerful ruling families, or factions within them, as the legitimate rulers over their people and their domains. Second, British protection and recognition of the rulers of the Trucial Coast also helped to empower most of them to dominate the independent rulers and tribal leaders of the interior, whom the British had not recognized. The result was the conversion of the interior shaikhdoms and tribal territories into dependencies of the coastal shaikhdoms. Third, British protection came at a high price: accountability to the Gulf Resident for any action he disapproved of. Fourth, the Gulf Resident supported only those rulers who co-operated with him to maintain the Pax Britannica, and kept out of power those who did not. Fifth, if the rulers found themselves at odds with British interests and refused British "advice" on the protection of those interests, they risked British intervention. A more serious dilemma occurred when the rulers found themselves trapped between the competing interests of their people and the British Government of India, later the British Government in London. The rulers needed the support of both groups. If they sided with their people, they risked British intervention. If they sided with the British, they undermined their legitimacy in the eyes of their people.

James Onley (CIRS Senior Fellow, 2008-09) is former Director of the Gulf Studies programme and Senior Lecturer in Middle Eastern History at the Institute of Arab and Islamic Studies, University of Exeter, England. He specializes in the history, society, and culture of the Gulf Arab states. He holds a DPhil from the University of Oxford (2001), where he studied at St. Antony's College. He is the author of The Arabian Frontier of the British Raj: Merchants, Rulers, and the British in the Nineteenth Century Gulf (Oxford University Press, 2007) and has articles/chapters in Nerw Arabian Studies (2004), Comparative Studies of South Asia, Africa, and the Middle East (2004), Transnational Connections and the Arab Gulf (2005), Journal of Social Affairs (2005), Maghreb-Machrek (2006), History and Anthropology (2006), The Gulf Family: Modernity and Kinship Policies (2007), and Asian Affairs (2009). He is the recipient of dissertation awards from the Middle East Studies Association of North America (2001) and the British Society for Middle Eastern Studies (2002). Before joining academia, Onley served in the Canadian Army for twelve years and was a UN peacekeeper in Iraq at the end of the Iran-Iraq War. 


\section{Sovereignty and Boundaries in the Gulf States: Settling the Peripheries}

J. E. Peterson

The concept of territorial boundaries for the states of the Gulf Cooperation Council (also referred to in this study as the Gulf states) is a relatively new phenomenon. Until recently, a principal difficulty in conceiving of territorial boundaries, let alone defining them, was the alien nature of boundaries themselves, the lack of any need for them, and the absence of putative states in most of the Peninsula. It was not until well into the 20th century - and in some cases late in the century - that the nature and the form of today's seven states became clear. In large part, the dynamics between today's states are derived from the jostling that took place as the states began to differentiate themselves.

Any examination of borders and boundary disputes should also consider the wider impact of the establishment of boundaries, as well as the persistence and sometimes resolution of disputes, on broader inter-state relations. In addition, it should be noted that the patchwork quilt of boundaries in the Peninsula are not conclusive or watertight and many observers consider that they would not stand the test of international law. In most cases, the settlement of frontier arrangements between any two countries was achieved without reference to their neighbors, even in areas where their common border touched that of a third state.

Until well into the 20th century, the concept of nation-state was alien to the Arab littoral. States were either dynastic, ebbing and flowing with the strength of particular leaders, or tribal, equally fluid. The territorial extent and boundaries of such states fluctuated on a regular basis and represented the relative strength of the neighboring actors far more than any legal, recognized format. The transformation of pre-state leaders into rulers of states owes much to the British role in the Gulf, although this does not explain all rulers. More recently, independence and membership in the international community has added its own impetus to the solidification of territorial nation-states through the introduction of the concept of citizenship, among other endeavors.

The settlement or non-settlement of boundaries owed much to the perpetuation of inter-state dynamics over the course of the past several centuries and into the independent period. That is to say, boundary issues had baggage of both territorial and political natures. In some or many cases, the settlement of specific disputes had to await the normalization of broader relations between the concerned parties.

There are various ways of classifying boundaries. This study proposes five categories that help explain the various natures and causes of boundary evolution and border disputes: (1) boundaries as an aspect of state formation; (2) boundaries as assertions of historical rights; (3) boundaries as imperial remnants; (4) boundaries as claims to natural resources; and (5) boundaries as manifest destiny, particularly in reference to Saudi Arabia. The study examines a selected number of representative border issues to illustrate these points.

J.E. Peterson is a historian and political analyst specializing in the Arabian Peninsula and Gulf. He has taught at various universities in the United States and has been associated with a number of leading research institutes in the United States and abroad. Until 1999, he served in the Office of the Deputy Prime Minister for Security and Defence in Muscat, Sultanate of Oman. Peterson is the author or editor of a dozen books, the most recent of which are Defense 
and Regional Security in the Arabian Peninsula and Gulf, 1973-2004: An Annotated Bibliography (Gulf Research Center, 2006); Historical Muscat: An Illustrated Guide and Gazetteer (Brill, 2007); and Oman's Insurgencies: The Sultanate's Struggle for Supremacy (Saqi, 2007). He has also published some 40 scholarly articles in such journals and annuals as: American Historical Review, American-Arab Affairs, Arabian Studies, Asian Affairs, Encyclopadia Britannica, Hoover Institution Yearbook on International Communist Affairs, Middle East Journal, Middle East Policy, Orbis, RUSI/Brassey's Defence Yearbook, Survival, and Washington Quarterly, as well as over 20 contributions to edited works. Peterson is presently working on a book on the recent history of Oman since 1970 and a modern history of Arabia. 


\section{Security Dilemmas in the Contemporary Persian Gulf}

Fred Lawson

Security dilemmas are central to the study of international relations. Unfortunately, the term "security dilemma" is most often used in a loose or simplistic fashion. Rather than examining in detail the dynamics that characterize the irresolvable dilemma(s) that states confront in an anarchic arena, students of world politics tend to use "security dilemma" as a synonym for "security problem" or "security challenge." And seldom do observers spell out the peculiar dilemmas that shape inter-state interaction in specific parts of the world.

International relations in the contemporary Gulf are shaped by four fundamental security dilemmas. First, each state in the region confronts the choice of whether to invest in security-producing programs and run the risk of provoking dangerous responses on the part of surrounding states, or to use its resources for other purposes and leave itself vulnerable to threats from its neighbors. Second, each Gulf state faces the dilemmas that are inherent in attempts to deal simultaneously with allies and adversaries. Third, these governments must decide whether to develop armed forces of their own or instead to contract with outside powers to provide their defense. Finally, these states have to choose between keeping the Gulf as insulated as possible from global rivalries and disputes and constructing strategic partnerships with external patrons. None of these four dilemmas can in any meaningful sense be resolved; each can only be managed for a limited period of time.

In practice, the Arab Gulf states and the Islamic Republic of Iran have opted to devote significant resources to procure and deploy a wide range of armaments, thereby engendering mutual mistrust and increasing the possibility that minor disagreements will erupt into military conflict. At the same time, the Gulf countries have for the most part chosen to contract with the great powers to supply external defense, even if such connections end up undercutting their internal legitimacy or sparking the rise of opposition movements that jeopardize domestic stability. Furthermore, local regimes have opened the door to substantial foreign involvement in Gulf affairs, raising the possibility that competition among outside actors will be reflected in regional diplomacy.

Taken together, these policy choices severely diminish the prospects for orderliness and peace in this part of the world for the foreseeable future. Yet, alternative policies would produce equally problematic consequences. Spelling out the dilemmas that are associated with security dynamics in the contemporary Gulf illuminates the difficulties with which local governments wrestle in their ongoing relations not only with one another but also with powerful external actors.

Fred H. Lawson is Rice Professor of Government at Mills College, where he has been teaching international relations and Middle East politics since 1985. He is author of Social Origins of Egyptian Expansionism during the Muhammad Ali Period (Columbia University Press, 1992); Why Syria Goes to War (Cornell University Press, 1996); Constructing International Relations in the Arab World (Stanford University Press, 2006); and other studies of political economy and foreign policy in the Middle East. He has held Fulbright lecturerships at the University of Aleppo (1992-93) and Aden University (2001). 


\section{The GCC States' Perceptions of Collective Security in the Early 21st Century \\ Joseph Kostiner}

The 21st century has confronted the GCC with a changing regional climate that has presented new challenges to the GCC's security. New challenges, which include domestic Islamist terrorism, Sunni-Shi'i sectarianism, and the uncertainty of the intentions of a newly resurgent Iran with nuclear and hegemonic aspirations. In light of these threats, the GCC has had to address the issues of collective security and regional defense. The GCC states have not developed a concrete framework for military cooperation but instead have attempted to develop common threat perceptions and unified responses. This study focuses more on unofficial manifestations of Gulf collective security, especially common views, like-mindedness of strategic outlooks, and similar political approaches among GCC leaders.

GCC security perceptions can be viewed on three levels. The first is the Gulf states' military reliance on the US and its limitations. The GCC's strategic relationship with the United States has been both an asset and a liability. The US has been the GCC's primary defender since the 1980s and is also the primary supplier of weapons and military technology to the Gulf. This strategy is limited due to internal Islamic opposition, fierce criticism from surrounding states such as Iran, and the presence of American installations, which have become targets for terror attacks. Consequently, the Gulf states distanced themselves from US actions in Iraq and even criticized the American occupation, regarding Washington as the primary cause of the outbreak of sectarian conflict in Iraq, and fearing its spread to Gulf territories. Additionally, they have remained wary of the intentions of the Shi'i-dominated Iraqi government and have resented strong US support for it. However, by the end of 2006, the threat of sectarian violence somewhat abated. While the GCC states have varying concerns regarding Iran's bid for regional power and nuclear development, they resisted US initiatives to join an anti-Iranian coalition to condemn Iran openly. They preferred to approach Iran with conciliation and caution.

A second level of Gulf security has been the reliance on diplomacy to prevent and diffuse conflicts. Gulf states such as Saudi Arabia and Qatar attempted to mediate regional conflicts in Iraq, Palestine, and Lebanon to promote Arab consensus and maintain calm in the region. They thereby attempted to limit Iranian influence in the region. Diplomacy served as a means to advance ties between GCC states and other states in the region, notably Egypt and Syria, which were both instrumental in bestowing legitimacy to Gulf positions and refuting regional media criticism against Gulf states. They also used diplomacy to overcome disputes and differences that had developed within the GCC itself.

The third level focuses on the practice of alliance building within the GCC. While the need to establish a strategic pact among GCC states is evident, structural problems, fears of an increase in Saudi power among the smaller GCC states - in the event of the establishment of such a pact — as well as GCC states' distrust of Arab military capabilities to defend them resulted in their abstention from agreeing to the establishment of such a strategic military pact. Additionally, they shunned any military alliance with Arab states such as Egypt and Syria. The one successful measure of security cooperation has been the Peninsula Shield, the GCC's multinational defense force. However, in the aftermath of the collapse of Saddam Hussein's regime and in light of an unclear strategic situation, Gulf leaders have disagreed over their vision for the future of the Peninsula Shield and, instead, focused on procuring more weapons from the United States. The GCC states have maintained their reliance on the United States on a bilateral basis, rather than creating a regional defense organization linked to the United States.

GCC states have still not developed a uniform policy or common framework to address emerging threats, reflecting differences in the interests of the individual GCC states. In spite of these differences, the Gulf states have displayed 
a high level of consensus, regarding regional security, and all of the Gulf states have preferred diplomatic action to maintain amicable relations with various, sometimes conflicting, factions. In keeping with their non-aggressive posture, the GCC states have placed themselves in a perpetual balancing act intended to offset cross-pressures emanating from the United States and Iran, while at the same time striving to cultivate an Arab consensus. GCC policy aims at finding a functional middle ground between similar but individual state interests, and this is demonstrative of the difficulties of establishing a clear and coherent policy among GCC states.

Joseph Kostiner, is a Senior Research Fellow at the Moshe Dayan Center for Middle Eastern and African Studies and is also an Associate Professor in the Department of Middle Eastern and African History at Tel Aviv University. He previously served as the Chair of the School of History from 200-2004. He is author of The Struggle for South Yemen (1984); South Yemen's Revolutionary Strategy (1990); From Chieftaincy to Monarchical State: The Making of Saudi Arabia 1916-1936 (1993); Yemen: The Tortuous Quest for Unity, 1990-1994 (1996). Co-editor (with P.S. Khoury) of Tribes and State Formation in the Middle East (1991). Editor of Middle East Monarchies (2000). 


\section{American Policy toward the Persian Gulf: Strategies, Effectiveness, and Consequences}

Mohammed Ayoob

This study argues that the international politics of the Persian Gulf, and especially American policy toward the Gulf, cannot be understood in isolation from the two contiguous sub-regions - the Arab heartland of the Middle East, Pakistan, and Afghanistan - to the west and east of the Persian Gulf. The three sub-regions, together constituting west Asia, are joined not only by common cultural and religious factors such as Arabism and Islam but are also perceived as a unified strategic theater by the United States as the constitution of Central Command (CENTCOM) clearly denotes. Even the factor unique to the Gulf, namely, its huge energy resources, is intimately intertwined with the politics of the contiguous regions as the Arab oil embargo of 1973, and the American response to the Soviet invasion of Afghanistan demonstrated.

This research then looks at the evolution of American policy toward the Persian Gulf sub-region from the end of World War II when the US took over the British mantle as the managerial power in the West Asian region. It analyzes the American policy of using surrogates, such as Iran, Saudi Arabia, and Iraq, to protect its strategic interests in the region in the 1970s and 1980s. The failure of this policy has led to massive direct military involvement by Washington in the Persian Gulf beginning with the first Gulf War of 1991 and culminating in the 2003 invasion of Iraq. This strategy has turned the US from being an off-shore balancer into the military hegemon of the region. However, such military hegemony has not produced commensurate political benefits. The United States is stuck in the Iraq and Afghan quagmires and its stock in the entire region, including the Gulf, has declined precipitately during the past decade.

The two major reasons for what amounts to America's political failure in the Gulf despite the massive military might it has been able to deploy are: (a) its inability or unwillingness to accommodate the premier indigenous power, Iran, into a stable security structure; and (b) its endorsement of Israeli actions vis-à-vis the Palestinians, including the recent disproportionate attacks on Gaza, that have alienated Muslim/Arab public opinion in the entire West Asian region where the US has now come to be perceived as the surrogate for Israel. While this has not had a direct effect on the energy issue so far, greater democratization of energy rich countries in the Gulf may see its impact flow through on energy supplies and pricing as well.

The initial rhetoric of the Obama administration and its choice of personnel to deal with West Asia do not denote any substantive change in American policy toward the region. This means that the United States will be stuck in the same quagmire that it has been in during the past decade. The West Asian region, including the Gulf, will continue to be unstable, existing problems will continue to fester, new problems including further terrorist activities are likely to emerge, and American popularity in the region will continue to be in the single digits. Such a situation will redound in favor of the radicals, Islamists and non-Islamists alike.

Mohammed Ayoob is University Distinguished Professor of International Relations, Michigan State University. A specialist on conflict and security in the Third World, his publications on the subject have included conceptual essays as well as case studies dealing with South Asia, the Middle East, the Persian Gulf, and Southeast Asia. He has acted as a consultant to the International Commission on Intervention and State Sovereignty; the High Level Panel on Threats, 
Challenges and Change appointed by the UN Secretary General; and the Ford Foundation. Ayoob has authored, co-authored, or edited thirteen books and published about ninety research papers and scholarly articles in leading journals such as World Politics, International Studies Quarterly, International Studies Review, Foreign Policy, International Affairs, International Journal, Survival, Orbis, Asian Survey, World Policy Journal, Global Governance, Alternatives, Third World Quarterly, Washington Quarterly, Middle East Policy, International Journal of Human Rights, Australian Journal of International Affairs, and as chapters in edited volumes. His books include The Politics of Islamic Reassertion (St. Martin's Press, 1981), The Third World Security Predicament: State Making, Regional Conflict, and the International System (Lynne Rienner Publishers, 1995), The Many Faces of Political Islam (University of Michigan Press, 2008), and Religion and Politics in Saudi Arabia: Wahbabism and the State (Lynne Rienner Publishers, 2009). 


\section{The Iraq Factor: Regional Consequences of Internal Turmoil \\ Daniel Byman}

Iraq is moving away from the abyss of all-out civil war that it teetered on in 2006, but it is still far from being a stable country. Terrorism within Iraq remains a tremendous problem, with suicide bombings and other attacks occurring on a regular basis. Warlordism and a lack of the rule of law plague much of the country: the central government's writ is weak, and, in many parts of the country, clearly secondary to local figures. Indeed, the US effort to work with local leaders to defeat Al-Qaeda in Iraq (AQI) has exacerbated this problem. Internal divisions, always considerable, are strong, with tension between communal groups — and just as importantly, within them - at times flaring up into violence. Iraq's economy is stalled, and its middle class decimated by war and emigration.

At the very least, Iraq will remain a limited source of instability for its neighbors and other regional states. Should Iraq return to the dark days of 2006, the risk of instability spreading from Iraq to neighboring states is far greater. Because stability in Iraq is so tentative, and because it depends on many factors that are difficult to predict and even harder to control, a US and regional priority should be to prevent the Iraqi conflict from spilling over and destabilizing neighboring states: an approach that requires preventing neighboring states from intervening, helping mitigate the risks associated with refugees, and striking terrorist havens, among other measures.

Daniel Byman is the Director of Georgetown's Security Studies Program and the Center for Peace and Security Studies as well as an Associate Professor in the School of Foreign Service. He is also a Senior Fellow with the Saban Center for Middle East Policy at the Brookings Institution. He has served as a Professional Staff Member with the 9/11 Commission and with the Joint 9/11 Inquiry Staff of the House and Senate Intelligence Committees. Before joining the Inquiry Staff he was the Research Director of the Center for Middle East Public Policy at the RAND Corporation. Byman has also served as an analyst on the Middle East for the government. He is the author of The Five Front War: The Better Way to Fight Global Jibad (Wiley, 2007); Deadly Connections: States that Sponsor Terrorism (Cambridge, 2005); Keeping the Peace: Lasting Solutions to Ethnic Conflict (Johns Hopkins, 2002); and co-author of Things Fall Apart: Containing the Spillover from the Iraqi Civil War (Brookings, 2007) and The Dynamics of Coercion: American Foreign Policy and the Limits of Military Might (Cambridge, 2002). He has also written widely on a range of topics related to terrorism, international security, and the Middle East. 


\section{Saudi Arabia’s Regional Security Strategy \\ Gregory Gause}

Saudi Arabia's regional security strategy has remained remarkably consistent in the decades since the Middle East emerged from colonial control as an autonomous regional system. The overriding goal of Saudi regional policy has been to maintain the security of the regime, in the face of both conventional regional military threats and in the face of transnational ideological challenges to the regime's domestic political stability and legitimacy. The pursuit of that goal, regionally at times, has created tension for the Saudi leadership in their most important international security relationship, that with the United States, but Riyadh has more or less successfully managed those tensions. This study assesses the Saudi regional security strategy on two geographic levels: the Saudis' immediate neighborhood, the Arabian Peninsula, where they assert hegemony; and the broader Middle East, where the Saudis have to deal with numerous powerful regional states. It discusses the means used by Riyadh to secure Saudi interests in the region, including financial power, diplomatic balancing and its own transnational ideological networks. It concludes with an analysis of Saudi regional policy since the Iraq War of 2003.

Saudi regional security policy cannot be understood simply in terms of the framework of national security. The Saudi ruling elite also uses its regional policy to secure the political stability of the regime against both foreign and domestic challengers. Regime security can be threatened by military invasion and conquest, but it can also be challenged by transnational ideologies and movements, which can mobilize domestic opposition to the ruling elite. In the Middle East, there are powerful trans-border identities grounded in Islam and Arabism which have attracted the political loyalty of publics across state borders. The Saudi regime has, in the past, been particularly vulnerable to such transnational ideological appeals. It has conducted a regional strategy aimed at balancing not simply against stronger regional military powers, but also against regional actors who try to employ transnational ideologies to penetrate Saudi society and mobilize Saudi citizens against their government. Being a weak power militarily, the Saudis have used their financial power and their own transnational ideology, salafi Islam, to advance their interests and counter the power of other regional states.

Since the fall of the Bathist regime in Iraq in 2003, Saudi Arabia has found itself thrust, uncomfortably, into a regional leadership role. The rise of Iranian power and the subsequent increase in Iranian influence in Iraq, Hizballah's successes in Lebanon, Iran's championing of Hamas in Palestine, and the development of Iran's nuclear program confronted the Saudis with a rising regional challenger. The Saudi approach toward the rise of Iranian power, to the end of 2008, has been a subtle effort to both engage and contain Iran. The problem for Riyadh is that the policy has not been very successful. It is therefore possible that the Saudis will employ a more confrontational stance toward Iran in the future.

F. Gregory Gause, III is professor of political science at the University of Vermont. From 1997 to 2008 he was also director of the University's Middle East studies program. He was previously on the faculty of Columbia University (1987-1995) and was Fellow for Arab and Islamic Studies at the Council on Foreign Relations (1993-94). He has published two books and numerous articles on the Arabian Peninsula. His forthcoming book, The International Relations of the Persian Gulf, will be published by Cambridge University Press in 2009. 


\section{Iran's Regional Foreign and Security Policies in the Persian Gulf}

\section{Mehran Kamrava}

A history of territorial and other disputes, often made all the more intractable by the advent of the modern state and by age-old cultural and linguistic differences, has resulted in deep-seated mistrust, suspicion, and acrimony between Iran on the one side and its Arab neighbors on the other. At the same time, the two sides have multiple points of convergent interests, not the least of which are strategic and commercial. Ultimately, pragmatic concerns and pursuits, rooted in on-going assessments of Iran's capabilities and needs, have guided the country's foreign and national security policies, both in relation to the larger world and, particularly, insofar as the Persian Gulf region is concerned.

With pragmatism as its primary guiding force, the substance and underlying logic of Iran's relations with its Persian Gulf neighbors, and with the outside world at large, have remained largely consistent since the mid- to late1990s. This is despite the tenure in office in Tehran of two very different presidents, one championing the cause of "dialogue among civilizations" and the other a radical rhetoric reminiscent of the early days of the revolution. This begs the question of why, then, did Iran's relations with the European Union and the United States deteriorate so dramatically during Ahmadinejad's presidency despite the continuity of his policies with those of Khatami? The answer has to do less with Iranian foreign policy than with larger international developments occurring around the time of changing administrations in Tehran, particularly significant improvements to US relations with a number of European powers that had become strained in the run-up to the US invasion and occupation of Iraq. Since France and Germany, and even Russia and China, among many others, had so doggedly opposed America's single-minded march toward war with Iraq in late 2002, early 2003, they were reluctant to enter into another row with their traditional ally over Iran's nuclear program. In the meanwhile, Ahmadinejad's tactless speeches and his confrontational personality made it significantly easier to vilify Iran and to present it as "a menacing threat" regionally and globally. In fact, at times Bush administration officials appeared far more concerned about Iran's threat to its neighbors than the neighbors themselves. In short, it was not the substance and nature of Iranian foreign policy or is security posture toward the Persian that changed from Khatami to Ahmadinejad. Rather, it was American foreign policy objectives, and with it the evolving nature of America's relations with its allies in Europe and in the UN Security Council, that underwent dramatic changes before and after 9/11 and the US invasion of Iraq.

Iranian foreign and security policies in relation to the Persian Gulf region have featured certain consistent themes, or, more aptly, areas of continued attention as well as tension. The first feature revolves around the broader military and diplomatic position that Iran occupies in relation to the Persian Gulf itself. Equally influential in Iran's regional diplomacy is what Tehran sees as "the Saudi factor," namely Saudi Arabia's posture and pursuits in the region. Iran's regional security policy, in the meanwhile, is largely determined by the role and position of the United States in what Iran considers to be its rightful sphere of influence. By extension, for Tehran, questions about Saudi diplomatic and American military positions and intentions bear directly on the nature and direction of Iran's relations with Iraq and Afghanistan.

The future of Iran's relations with its Persian Gulf neighbors cannot, therefore, be examined without also considering Iran's relationship with the United States. It is difficult to imagine US-Iranian relations darkening any worse than they had during the administration of George W. Bush. Any reduction of tensions between Iran and the United States is likely to be welcomed by the regional states, many of whom worried, with good reason, about the potential fall-out of any open conflict between Tehran and Washington. But many regional actors also worry about the possibility that a 
warming of relations between Iran and the United States may lessen their luster in Washington's eyes. A domestically weakened and internationally castigated Iran may be the preferred option of its neighbors, but whether this is a more likely scenario than an Iran which is more integrated into the international community, perhaps led by a different president, depends as much on larger international developments as it does on Iran's domestic politics and policy preferences. Changes are surely in the offing. What remain to be seen are their degree, intensity, and direction. 


\section{Qatar's Foreign Policy: Autonomy and Security}

Steven Wright

This study seeks to examine the drivers and the unique character of importance that Qatar's foreign policies displayed within the Gulf region and the global community. With Qatar possessing the third largest reserves of natural gas, coupled with its emergence as the leading global producer and exporter of Liquefied Natural Gas (LNG) and Gas to Liquid Fuels (GTL), its importance in the global energy supply matrix, and its related foreign policies, are of particular interest in international relations. This is both within the Gulf Cooperation Council (GCC) and on global levels. Yet, since the early 1990s, Qatar's foreign policy has emerged as something of a paradox. Qatar has taken on a unique and dynamic character within the region as it has embraced policies which can be understood as distinct from the foreign policies of the other GCC states and has broken with the important common positions they have taken. Its diplomacy regarding Iran and Israel is a clear example of this, as is its willingness to allow for an unfettered satellite media through the Al Jazeera network. Its engagement in high profile conflict resolution diplomacy further complicates our understanding of Qatar's foreign policy drivers, influences, and objectives. Qatar is therefore an important case study on how and why foreign policy is changing within the GCC and thus offers lessons on how an increasingly globalized region is making a departure from the past. The structure of the study is as follows:

Regional Geopolitical and Historical Context: In the introductory section, the geopolitical influences on the formation of Qatari foreign policy will be addressed. This will be in particular regard to the question of security and autonomy of action. Qatar's relations with the United States, Saudi Arabia, Iran, and Bahrain form a significant proportion of this section. However, it will also seek to provide explanation on how changes at the domestic decision-making level, in addition to idiosyncrasies of elite decision-makers, have impacted on the policies adopted. Indeed, during the initial years of Sheikh Khalifa bin Hamad al Thani's reign, decision-making and policy-formation proved to be largely centralized and patrimonial in character. It was the changes to the decision-making structures leading towards a more diffuse system with a greater deal of autonomy, which were to sow the seeds for the structural pluralism of later years. This in turn would impact the character of Qatar's future foreign policy and overall economic development strategies.

Diversification of Security: Qatar's energy reserves make it a major player in the global energy supply matrix. Its energy policy is economically grounded in that it is dictated by the fundamentals of supply and demand, with energy contracts going to the market where the highest price or volumes can be achieved. Yet, by providing a significant proportion of foreign countries' energy needs, it is creating "stakeholders" in its own stability and security. While this does not necessarily translate into the hard-security guarantee that Qatar enjoys with the United States, it caters for profile-building, influence, and stronger diplomatic ties with key countries, all of which enhance Qatar's soft-power security. In other words, although energy policy may not necessarily be fully integrated with Qatar's foreign policy, it indirectly offers Qatar what can be considered a supplemental security diversification. Therefore, this study will provide an overview of how Qatar's energy sector is indirectly enhancing the mainstream foreign policy. A further related issue will seek to show how Qatar is playing a key role in fulfilling regional energy demands. The Dolphin project shows how neighboring UAE and Oman have to import Qatari gas in order to fulfill their domestic energy needs. A clear question here is what impact is this likely to have on Qatari foreign relations in the future given that the opportunity costs for natural gas supplies are much greater in the global rather than regional markets.

16 International Relations of the Gulf | Summary Report 
In addition to the power generated by Qatar's energy supplies, the Al Jazeera media network has had a far-reaching impact on the region. For Qatar, it is also a soft-power as it is understood to have editorial independence. It is important to recognize that the autonomous application of freedom of speech and editorial independence to this agency is a crucial issue as it gives journalists carte blanche to focus on issues considered the most newsworthy for its regional audience. In several respects, it is reasonable to conclude that this would increase the type of journalism which has so often proved unpalatable with several governments. Therefore, this study will aim to show that although the allowance of free speech is clearly a progressive liberalization, it is also something of a double-edged sword: on the one hand, it has resulted in regional recriminations against Doha by neighboring states and on the other, it has been an innovative method of projecting political power and influence, which arguably enhances Qatar's national-security.

Conflict Resolution and Security Diversification: The study also explores why Qatari foreign policy has evolved into one with regional and global stretch in the form of conflict resolution. Why is it occurring, and what does it show us in terms of diplomacy? The manner in which Qatar has sought to enhance its national security has allowed for a greater degree of autonomy in foreign policy, especially since a hard security relationship with the United States was formalized. Qatar has become engaged in back channel diplomacy and high profile conflict resolution in Lebanon, Yemen, Sudan, Libya, and Iraq, among other countries. The high profile Doha-brokered agreement between the contesting parties in Lebanon in 2008 is particularly worthy of note, and the parties being flown to Doha shows Qatar's willingness to engage in high profile summit-style diplomacy. Indeed, Qatar's desire to play a leading role in such diplomacy was underlined by its stance on the Israel-Gaza conflict in January 2009. Although the achievement of security allows for autonomy of action, Qatar's dynamic role in regional conflict resolution and mediation leads the researcher to question what its underlying motives are given that they are obviously not related to achieving autonomy and security.

Steven Wright is an Assistant Professor in International Affairs at Qatar University. He was formerly based at Durham University's Institute for Middle Eastern and Islamic Studies as the Sir William Luce Research Fellow. Wright specializes on the Gulf states, with particular regard to Qatar and Bahrain. He was educated at the University of London where he received a degree in social and political science, and at Durham University where he obtained a Masters in International Studies and a Ph.D. in International Relations of the Gulf Region. His research is focused on Qatar's political economy and foreign relations. His publications include The United States and Persian Gulf Security (Reading: Ithaca Press, 2007). "Fixing the Kingdom: Political Evolution and Socio-Economic Challenges in Bahrain" (CIRS Occasional Paper No. 3, Georgetown University, SFS-Qatar, 2008). 


\section{China, India and the Gulf-Converging Interests? \\ N. Janardhan}

At a time when the Gulf countries are attempting multi-dimensional changes that bear the potential to transform the region and Asia is experiencing a renaissance, there exists an opportunity for synergy to accomplish optimum mutual benefits even beyond the economic realm.

While the Gulf-Asia interface boasts of a vibrant historic past, the interaction suffered during the reign of colonial powers. In the recent past, however, several regional and international events have given scope for the re-establishment of the old bonhomie. Economic factors are bound to remain the bulwark of the emerging relationship, with Gulf-Asia trade figures increasing several times in the last seven years. The energy resources from the region are vital for the Asian markets. The accumulated oil capital is scouting for investment prospects that guarantee higher returns than in the West, which is becoming available in Asia's push for infrastructure, even during the period of global economic slowdown.

Asia consumes 23 million barrels per day, which is 30 percent of the world's demand. The Gulf Cooperation Council (GCC) countries, for example, export two thirds of their oil output to Asia, which could more than double during the next two decades. Further, more than half of GCC exports go to Asian countries while a third of GCC imports are from Asia. Partly as a result of 9/11 and partly due to the surge of Asian economies, the East is also the Gulf's preferred market. This "Look East" policy in the economic realm comes at a time of regional introspection in the political arena too, which is likely to influence the long-term political economy of the Gulf countries and shape international relations in the coming decades.

Looking beyond these issues, the partnership with Asia serves as a platform for the Gulf countries to convey their determination to break the conservative stereotype attached to them in the international milieu and showcase their new relentless march on the path of reform and progress to become an integral part of the globalized world. Among the Asian countries that have not only consolidated their place on the continent, but are also making their presence felt on the global stage are China and India - two great civilizations with different post-colonial development models, different social as well as political setups, different oriental attributes, and, most importantly, different economies that together account for more than a third of the world's population.

While being rooted in the prevalent economic dynamics, the aim of this study is to emphasize the need for converting the prevalent 'opportunity' into a 'strategy.' It raises ideas and elicits responses on what the future course of the relationship among India, China, and the Gulf could be beyond the economic realm. The premise is that the Gulf's "Look East" policy has to go beyond preferential trading arrangements and newfound political warmth, and address security strategies as well. The focus is not to lay out a formula, but to try and build an argument that looks beyond the US-centric security paradigm that prevails in the Gulf. The premise again is that the Gulf countries would take Asia seriously only if it is willing to be involved beyond trade.

The "rediscovery" of interest between Asia and the Gulf, and plans to build a new outlook could be sluggish because of some intrinsic differences on both sides. Notwithstanding the historic Gulf-Asia ties which have been sustained by the current oil, trade, and expatriate dynamics, the way forward for a robust bilateral relationship rests on developing a paradigm that hinges on strategic political, economic, and security dimensions.

There is an increasing call for the Gulf region to act independently, take stock of the situation, and design future security arrangements without leaving everything for the United States to formulate. It is true that though the region's 
ties with both Asia and Europe are expanding, there is no other international actor that can replace the United States in the short- or medium-term future. It is also true that while both have expressed their concerns about the regional security environment, neither has yet shown any concrete sign of investing in the hard security mechanisms that the Gulf requires. But that could change during the next couple of decades.

Among the Asian countries that can be easily identified as having the potential and the inclination to play a security role in the region are China and India. Both are military powers in their own right, and, given the current level of economic engagement, they are bound to take part in any arrangement that safeguards their interests, thereby overlapping with the security of the region. Some of the developments in and statements of each of these countries suggest that the possibility of an Asian role in the security architecture of the Gulf is more than just rhetoric in the long-run.

This study explores the factors that may condition Chinese and Indian roles in the Gulf region, especially related to US-Iran ties, GCC-Iran ties, the approach towards China and India, Iran's relations with China and India, US-India versus China and, finally, the relation between India and China itself. In this context, a number of key questions need to be addressed: Are India and China willing to play a security role? Will they take the same path as the United Sates or decide to adopt a distinct and non-controversial approach? Even if they are interested in a wider role, how effective will they be? How will they balance their ties with Iran and Israel on one side and the GCC countries on the other? More crucially, is the region looking "out of the box" for their security or is the making a mountain out of a molehill while expressing long-term fears about Asia's intentions in the regional security architecture?

N. Janardhan is a UAE-based political analyst specializing in Gulf-Asia affairs. With a broad-based interest in the socio-political developments of the Gulf region, his research areas include political reforms, education, media, labour and international relations. With a $\mathrm{PhD}$ from the Centre for West Asian Studies, Jawaharlal Nehru University in New Delhi, Janardhan was editor of "Gulf in the Media," and Program Manager of Gulf-Asia Relations, at the Gulf Research Center in Dubai. He also worked with The Asian Age and The Gulf Today newspapers in India and the UAE respectively, and with the Rome-headquartered Inter Press Service as well. 


\section{Political Reform and Foreign Policy in the Gulf Monarchies \\ Katja Niethammer}

The recent political reform projects that Bahrain, Kuwait, Oman, Qatar, Saudi Arabia, and the UAE have undertaken have challenged earlier views of these political systems as being fundamentally backward. The six Gulf monarchies have started to experiment with elections and have introduced or expanded advisory or parliamentary councils. No doubt, the quality and significance of both elections and representative bodies vary greatly: some elections are indirect and/or take place only at municipal levels, and some councils have legislative powers, while others do not.

Do these domestic reforms potentially affect the GCC states' foreign policies? In order to produce such effects on foreign policy discourses, strategies, and outcomes, domestic reform projects would have to generate significant changes in three interrelated areas: first, reforms would have to introduce checks and limits on executive powers. Second, the degree of competitiveness in the selection of the executive would have to be altered, that is, new sets of elites would have to emerge. Third, political participation would have to be broadened in a way which could lead to an increased competition on the normative level.

The first and second conditions have not been met: an analysis of the reforms undertaken by the Gulf monarchies clearly shows that those policies consolidate autocratic rule. Ruling elites aim to enhance their legitimacy and to secure their rule against competitors from within their families. They never had in mind to subject their rule to a popular vote or to delegate substantial decision-making power to elected officials. The ruling elites in the GCC states are wedded even more firmly to their positions of authority than other authoritarian rulers. Their dynastic form of rule creates serious reform blockages as ruling families rely on their appropriation of state resources - in administrative positions, lands, industrial projects, and, of course, oil and gas rents. While the dominance that ruling families exert on the GCC states is in some respect comparable to that of hegemonial parties, it is harder for a ruling family to integrate other societal groups into their structure and into the core political elite. Other than hegemonial parties, GCC ruling families could not hope to win any elections, however closely managed. Paradoxically, while the dominance of the ruling families undermines their legitimacy, it simultaneously provides these states with high regime stability, as spaces for autonomous actors are rather marginal in this setting.

As political decisions are taken within primordially defined groups, they often take place outside of the formal institutions of parliaments and cabinets and are often taken by a circle of important ruling family members behind closed doors of royal or emiri palaces. This decisively limits the significance of the appointment of new ministers, as a ministerial post does not automatically confer decision-making power. Moreover, the concentration of power within primordially defined groups blocks transfers of power at the inter-state level: ruling elites have not provided the GCC with decision-making authority of its own but continue to conduct their foreign policies in a national framework.

A second blockage to reform is posed by the effects of the rentier economies: rent income provides the ruling elites with the means for cooptation and the establishment of large bureaucracies in which dissenters were integrated in the past, and also for repression. Moreover, their oil rents insulate the GCC's ruling elites from international pressure to some degree.

Thus, the reforms have designed specific aspects of institutions and drafted legislation in a way that perpetuates the dominance of the executive, as no separation of power has been achieved. Legislation pertaining to civil liberties and political rights either outlaws political associations completely or withholds legal certainty from them and from 
individual activists. Thus, the emergence of organized oppositional or alternative political actors is tightly controlled and even prevented. Decision-making remains firmly in the hands of the ruling elites.

Findings on the broadening of political discourses, however, are more ambivalent. Obviously, in those states such as Oman, Qatar, Saudi Arabia, and the UAE where reforms have been most limited — campaigning taking place only on a personal level, no or rare possibility to from associations, and limited access to information for the general public - a broadening of foreign policy discourse has not occurred. But the picture is less clear with regard to Kuwait and Bahrain. Both countries have active and well organized civil societies. Although legal foundations are deficient, NGO activism is mostly tolerated by the regimes. Bahrain has legalized so-called political societies as de-facto parties which campaign for elections on a party platform. Kuwait has no similar legislation but tolerates political party activism. In both countries, these proto-parties can hold public seminars and workshops, there is a somewhat oppositional local press, and foreign policies can be publicly debated. In these two states a broader discourse on state policies has emerged that might, in the long run, affect policy outcomes, including foreign policies. However, non-elite political actors even in these two states are largely preoccupied with pressing for domestic policy changes as trying to influence the GCC states' foreign policies is secondary to them. Moreover, the case of Bahraini Islamist actors shows that the authoritarian character of the state's reforms as well as the "post-modern" approach taken by the non-elite political actors ensure that the ruling elite is not endangered.

One positive conclusion can be drawn from these otherwise negative findings: the autocratic transitions to be witnessed in the GCC do not increase the likelihood of interstate violence as "real" democratization might.

Katja Niethammer is interim Director of the Institute for Islamic Studies at Hamburg University, where she is also a professor specializing in Islamic Studies. Niethammer completed her Ph.D. in Islamic Studies at the Free University of Berlin. From 2004-2008 she worked as a researcher at the German Institute for International and Security Affairs (Stiftung Wissenschaft und Politik, SWP), research group "Middle East and Africa." Before this, Niethammer worked as Academic Coordinator of the Interdisciplinary Center "Social and Cultural History of the Middle East" from 2001-2004, and as project manager for both the publishing group Georg von Holtzbrinck and the Berlin-based House of World Cultures (Haus der Kulturen der Welt). She is the author of Political Reform in Babrain: Institutional Transformation, Identity Conflict and Democracy (Routledge, forthcoming), "Opposition Groups in Bahrain" in Ellen Lust-Okar and Saloua Zerhouni (eds.), Political Participation in the Middle East (2008) Lynne Rienner, Boulder, Col.pp. 143-170; "The Paradox of Bahrain: Authoritarian Islamists Through Participation, Pro-Democratic Islamists Through Exclusion?" In Muriel Asseburg (ed.), Moderate Islamists as Reform Actors. Conditions and Programmatic Change. SWP Research Paper 4, Berlin, April 2007, pp. 45-54 and Political Reform in Babrain: Institutional Transformation, Identity Conflict and Democracy to be published by Routledge in 2009. 


\section{Conceptualizing EU-GCC Relations}

Gerd Nonneman

The long history of European-Gulf relations is not reflected in the specific EU-GCC (and prior to this, EC-GCC) relationship, which has been slow to develop and remains hamstrung by a number of factors. Among these are the obvious fact that the GCC was established only in 1981, and that the EC/EU itself has undergone a series of transformations. The death of the Euro-Arab Dialogue in 1989 heightened the perceived need to enhance the relationship between the Gulf and Europe specifically. While the EC/EU reformed its cooperation frameworks with the 'Mediterranean' states from 1990 - first in the Renewed Mediterranean Policy (RMP), then the 1995

Euro-Mediterranean Partnership Initiative (EMP) - the Gulf remained outside these initiatives. But Europe's relationship with it began to reflect some of their characteristics in a separate channel of its own: thus, the focus on regional and subregional integration, the focus on stability through political reform and economic liberalisation, the formatting of the relationship into three 'baskets' (political, cultural, and economic), a concern over sensitive sectors of the economy on both sides, and a problematic discussion about human rights and political issues. 1990 also saw the beginning of negotiations on an FTA - which, as of 2009, have been suspended after repeated yearly assurances that success was just around the corner.

Explanations for the patterns observed must be multi-level. Just as the formal EC/EU-GCC relationship does not equate to the much longer history of European-Gulf relations, neither must the collective group-to-group relationship's characteristics be confused with the wider set of relationships including crucial bilateral ones. Indeed the latter form part of the explanation for some of the features of the former. It is striking also that the evolution of European relationships with the Middle East and the Gulf appear to match broader structural changes in the global and European environment.

The group-to-group relationship is an example of 'inter-regionalism,' which in turn is intertwined with 'regionalism.'The factors that feed into the evolution of both 1) are to be sought at the domestic, regional, and global levels; 2) are both ideational and material; 3) comprise both structure and agency; 4) and include a significant degree of path-dependence.

More specifically, explanations for attempts to progress in the broad European-Gulf relationship include a set of 'positive interests' (economic and political/strategic) and other positive factors including history and personal attitudes. For the GCC, the interests include geo-economic and geo-strategic diversification. Factors affecting the particular shape and content of the evolving relationship include 'zeitgeist' (fashions), the relative positions of power, global structures, as well as particular interests. For the group-to-group, inter-regionalist relationship, enabling and constraining factors comprise a subset of the above - but factors enhancing bilateral and wider relationships between the two sides do not necessarily favour the collective 'inter-regionalist' relationship.

Factors favouring the latter - whether among the EU and the GCC or elsewhere - or at least explaining why regional blocs such as these may aim to enhance their collective relationship with the partner bloc may include attempts to reinforce and legitimate the role and identity of the region in question. It may also be seen as a means of managing global change, and as a way of establishing the region/bloc as a global actor. 'Fashion' certainly is also a factor - although not one necessarily independent from the other considerations and factors. These emerging insights from work on regionalism and inter-regionalism elsewhere (or indeed about the EU's interactions with other regions outside the Middle East) would seem to apply also for the EU-GCC relationship. 
The constraints in the formal EU-GCC relationship lie in diverging interests within both sides; the distinct history of particular bilateral relationships; the quite different nature of the two groupings and their structures, including in decision-making; the lesser 'actorness' of the GCC when compared to the EU; the role of other powers - particularly the U.S. (both directly and as perceived); and, latterly, the shifts in the global political economy and in the needs and capacities of the GCC economies, which arguably increased the relative importance of Asia in the foreign economic and diplomatic relations of the GCC states.

Gerd Nonneman is Director of the IAIS's Gulf Studies programme. After teaching Middle East politics and political economy at Manchester and Exeter Universities, and a spell as Visiting Professor at the International University of Japan, he taught International Relations and Middle East Politics at Lancaster University from 1993 to 2007, returning at last to his 'second home', Exeter, in the summer of 2007 to take up his present position. He was a member of the UKs 2001 national Research Assessment Exercise (RAE) panel on Middle Eastern Studies, and served as Executive Director of the British Society for Middle Eastern Studies (BRISMES), 1998-2002. He is also an associate Fellow of the Middle East Programme at Chatham House (Royal Institute of International Affairs), serving as the Programme's specialist on the Arab Gulf states.

Aside from his academic work, Nonneman has written for specialist political and economic analysis publications such as the Economist Intelligence Unit and acted as a consultant to or worked with a range of companies, national and international official institutions including the Foreign \& Commonwealth Office, foreign ministries in Europe and elsewhere, the European Commission, and various NGOs ranging from Amnesty International to the Bertelsmann Foundation. 


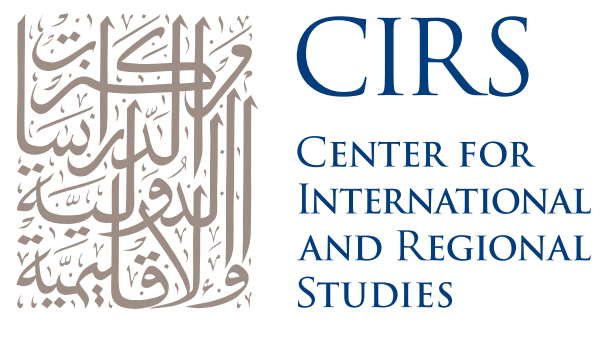

GEORGETOWN UNIVERSITY SCHOOL OF FOREIGN SERVICE IN QATAR 



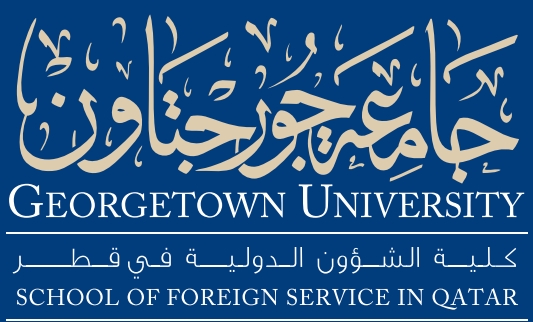

(C) 2009 Center for International and Regional Studies Georgetown University School of Foreign Service in Qatar

Qatar Foundation

P. O. Box 23689

Doha, State of Qatar

http://cirs.georgetown.edu

cirsresearch@georgetown.edu

Tel +9744578400

Fax +974 4578401 